\title{
Hen-Day Egg Production and Qualitative Egg Indices in Laying Hens Administered with Lycopene and Vitamin E During the Hot-Dry Season
}

Joseph Ayodele Obidi ( $\sim$ citradev377@yahoo.com )

Ahmadu Bello University

Joseph Olusegun Ayo

Ahmadu Bello University

Peter Ibrahim Rekwot

Ahmadu Bello University

Barth Izuchukwu Onyeanusi

Ahmadu Bello University

\section{Research Article}

Keywords: Hen-day egg production, Qualitative egg indices, Laying hens, Lycopene, Vitamin E, Hot-dry season

Posted Date: September 17th, 2021

DOl: https://doi.org/10.21203/rs.3.rs-833956/v1

License: (c) (i) This work is licensed under a Creative Commons Attribution 4.0 International License. Read Full License 


\section{Abstract}

The aim of the study was to evaluate the ameliorative effects of lycopene and vitamin E, administered individually and in combination, on laying hens during the hot-dry season. The dry-and wet-bulb temperature were recorded daily from 06:00-18:00 h during the 5-week experimental period. Daily and weekly hen-day egg productions, egg weight, eggshell thickness and eggshell weight were determined using standard procedures. The dry-bulb temperature $\left(23.0^{\circ} \mathrm{C}-39.0^{\circ} \mathrm{C}\right)$ and temperature - heat index $\left(24.4^{\circ} \mathrm{C}-35.0^{\circ} \mathrm{C}\right)$ recorded show that the hens were subjected to heat stress during the season. Egg production in the laying hens in lycopene $(62.4 \pm 1.1 \%)$, vitamin $E(62.1 \pm 1.2 \%)$ and lycopene + vitamin $E$ $(62.7 \pm 1.0 \%)$ groups were higher $(P<0.05)$ than in controls $(56.0 \pm 0.8 \%)$. Eggshell was thickest in lycopene + vitamin E group $(0.28 \pm 0.02 \mathrm{~mm})$, compared to lycopene $(0.23 \pm 0.02 \mathrm{~mm})$ and vitamin $E$ group $(0.22 \pm 0.02 \mathrm{~mm})$. The thickness was lowest $(P<0.05)$ in control hens $(0.18 \pm 0.02 \mathrm{~mm})$, compared to any other group. Similarly, control laying hens recorded the least $(P<0.05)$ in eggshell weight $(6.7 \pm$ $0.02 \mathrm{~g}$ ), compared to the weights recorded in lycopene + vitamin E, lycopene and vitamin E groups (7.3 \pm $0.24 \mathrm{~g}, 7.3 \pm 0.3 \mathrm{~g}$ and $7.2 \pm 0.3 \mathrm{~g}$, respectively). In conclusion, lycopene and vitamin E ameliorated the risk of adverse effects of heat stress by increasing hen-day production, eggshell weight and eggshell thickness during the hot-dry season.

\section{Introduction}

Oxidative stress is a critical factor implicated in the initiation, development and progression of most ovarian dysfunction, which may be exacerbated during the inclement hot-dry season in the Northern Guinea Savannah zone of Nigeria. In poultry production, various environmentally-induced stresses, ranging from poor nutrition (Opoku et al. 2015; Sahin et al. 2016; Surai et al. 2019), disease (QuinteiroFilho et al. 2010; Troxell, 2016), social stress (Mirfendereski and Jahanian, 2015) and heat stress (Star et al. 2008a, b) exert remarkable depressive effects on poultry well-being and optimum productivity (Star et al. 2008b). Heat stress results from outrages in environmental temperature often associated with the zone during the hot-dry season. Its severity is aggravated by concurrent increase in relative humidity, which impairs performance and induces oxidative stress in poultry. In the tropical environment, heat stress constitutes a major debilitating factor to poultry production (Rozenboim, et al. 2004; Elnager et al. 2010). It results from a negative balance between the net amount of energy flowing from the laying hen's body to its surrounding environment and the amount of heat energy produced by the hen. This imbalance may be caused by salient environmental factors, including sunlight, thermal irradiation, air temperature, relative humidity, air movements, metabolic rate, and impaired thermoregulatory mechanism. (Star et al. 2008a, b; Dzenda et al. 2013). Lycopene is the predominant carotenoid in tomatoes and one of the major carotenoids in the serum and tissues (Boileau et al. 2002; Palozza et al. 2012). When lycopene is incorporated in avian tissues, especially in egg yolk, it exhibits significant antioxidant activity (Olson et al. 2008). Lycopene quenches reactive oxygen species (ROS), including singlet oxygen and other oxidising species and, thus, protects the cells from oxidative damage (Khan et al. 2008; Wang et al. 2014; Sahin et al. 2016). Vitamin $E$ is an essential fat-soluble nutrient, often called tocopherol. Alpha-tocopherol is 
essentially the most predominant, with the highest biological activity in many species. Domestic birds do not synthesize enough vitamin $\mathrm{E}$ and, consequently, they are dependent on dietary sources to meet their body requirements (Surai et al. 2001, 2019; Surai 2020). Vitamin E supplementation in poultry nutrition improves fertility, hatchability and the qualitative post-hatch performance of avian chicks (Urso et al. 2015; Klasing and Korver, 2020), through better protection against oxidative stress (Lewis et al. 2019; Surai et al. 2019). It is a potent antioxidant involved in the prevention and management of infertility and other reproductive anomalies (Helmy and Senbel 2012; Klasing and Korver, 2020).

The aim of the study was to evaluate the effects of lycopene and vitamin E on hen-day egg production and qualitative egg indices in laying hens during the hot-dry season.

\section{Materials And Methods Location of the study}

The experiment was performed in a standard poultry farm in Zaria, located at latitude $11^{\circ} \mathrm{N}, 12^{2} \mathrm{~N}$ and longitude $7^{\circ} \mathrm{E}, 8^{\prime} \mathrm{E}$, elevation of $650 \mathrm{~m}$ above sea level, and in the Northern Guinea Savannah zone of Nigeria. The zone has annual mean maximum and minimum temperatures of $31.8 \pm 3.2^{\circ} \mathrm{C}$ and 18.0 $\pm 3.7^{\circ} \mathrm{C}$, respectively. The zone is characterised by three seasons: Harmattan (cold-dry) occurring in November-February, rainy (June - October) and hot-dry seasons (March - May) (Dzenda et al. 2013, 2015). The hot-dry season has been described as the most stressful to laying hens (Obidi et al. $2008 \mathrm{a}$, b).

\section{Thermal environmental data}

A dry- and wet-bulb thermometer (Mason's Type Wet-and Dry-bulb hygrometer (GH Zeal Limited, London, England), positioned at the height of $2 \mathrm{~m}$ from the floor in the experimental poultry pen was used to record the dry- and wet-bulb temperatures daily every three hours, beginning from 06:00 $\mathrm{h}$ to 18:00 $\mathrm{h}$, throughout the duration of the study that lasted for five weeks. The temperature-humidity index (THI), used to determine the heat load in the laying hens was calculated from the dry- and wet-bulb temperatures (Zulovich and DeShazer 1990):

\section{$\mathrm{THI}=0.6 \mathrm{~T}_{\mathrm{db}}+0.4 \mathrm{~T}_{\mathrm{dw}}$}

Where:

THI: temperature-humidity index for the laying hen $\left({ }^{\circ} \mathrm{C}\right)$

$\mathrm{T}_{\mathrm{db}}:$ dry-bulb temperature $\left({ }^{\circ} \mathrm{C}\right)$ 
$\mathrm{T}_{\mathrm{wb}}$ : wet-bulb temperature $\left({ }^{\circ} \mathrm{C}\right)$

\section{Flock management}

During the peak of the hot-dry season, 400, apparently, healthy ISA Brown laying hens, aged 41 weeks with a mean live weight of $1.8 \pm 0.5 \mathrm{~kg}$ were used for the study. They were maintained in deep litter in an open-sided standard poultry pen unit. The hens were divided by simple randomisation into four groups, comprising 100 group-penned laying hens each and maintained on layer mash (Vital Feeds Ltd., Jos, Nigeria). The feed had nutritive values of $16.50 \%$ crude protein, $6.5 \%$ crude fibre and $2650.0 \mathrm{kCal} / \mathrm{kg}$ metabolisable energy. The flock was given access to feed and water ad libitum. Standard routine vaccinations and periodic prophylactic medications were administered to the hens. The husbandry and the conduct of the experiments on the laying hens were performed in accordance with the European Convention for the Protection of Vertebrate Animals used for Experimental and other Scientific Purposes (Council of Europe No 123, Strasbourg 1985). All the experimental protocols described were approved by the Ethics Review Committee for Animal Experimentation of Ahmadu Bello University, Zaria, Nigeria.

\section{Experimental design}

The study was conducted on four different groups of laying hens in a laying pen, comprising 100 birds per group. Each pen was identified according to its experimental role. The lycopene-treated group was administered orally with $30 \mathrm{mg}$ lycopene/kg body weight per day (Sun et al. 2014), while the control group was given the equivalent of water only. The lycopene + vitamin E-treated birds were administered orally with $30 \mathrm{mg}$ lycopene, combined with $250 \mathrm{mg}$ vitamin $\mathrm{E} / \mathrm{kg}$ body weight per day, while the vitamin Epenned layers received vitamin E only at a dose of $250 \mathrm{mg} / \mathrm{kg}$ body weight per day (Sahin et al. 2002). All administrations were performed orally, using a gavage between 7:00 h and 8:00 $\mathrm{h}$ daily for five weeks, and feed and water were available to the birds ad libitum. The hen-day egg production and mean egg weight, as indices of egg production, in each pen were recorded daily. The weekly eggshell weight and eggshell diameter were evaluated throughout the study period as described by Mack et al. (2013).

\section{Data analyses}

The data obtained were expressed as mean \pm standard error of the mean (mean \pm SEM). Variations in hen-day egg production and eggshell qualitative indices of the laying hens were analysed using repeatedmeasures analysis of variance (ANOVA), followed by Tukey's multiple comparison post-hoc test. Values of $\mathrm{P}<0.05$ were considered significant. Data were analysed using GraphPad Prism, version 5.03. (GraphPad Software, San Diego, California, USA, www.graphpad.com).

\section{Results}




\section{Thermal environmental conditions}

The thermal environmental conditions of DBT and THI data are presented in Tables 1 and 2. Weekly mean DBT values were significantly $(P<0.05)$ lower during the morning hours between 6:00 $\mathrm{h}$ and 9:00 $\mathrm{h}$ than the values obtained at $12: 00,15: 00$ and $18: 00 \mathrm{~h}$. The lowest DBT $\left(24.3 \pm 0.5^{\circ} \mathrm{C}\right)$ was recorded at 6:00 $\mathrm{h}$ during the fourth week of the study, while the highest value $\left(36.7 \pm 0.6^{\circ} \mathrm{C}\right)$ was recorded at 9:00 $\mathrm{h}$ in the $3^{\text {rd }}$ week of the study (Table 1). The DBT varied significantly $(P<0.05)$ between 9:00 h and 12:00 h; thereafter, the variations were not significantly $(P>0.05)$ different.

\section{Table 1}

Weekly diurnal fluctuations in dry-bulb temperature $\left({ }^{\circ} \mathrm{C}\right)$ during the hot-dry season 


\begin{tabular}{|c|c|c|c|c|c|}
\hline & & & Time, $\mathrm{h}$ & & \\
\hline Week & $6: 00$ & 9:00 & $12: 00$ & $15: 00$ & $18: 00$ \\
\hline \multirow[t]{2}{*}{1} & $26.0 \pm 0.38^{a}$ & $27.3 \pm 0.4^{a}$ & $32.6 \pm 0.6^{b}$ & $35.43 \pm 0.8^{c}$ & $36.71 \pm 0.6^{c}$ \\
\hline & $(25.0-27.0)^{\star}$ & $(25.0-28.0)$ & $(30.0-35.0)$ & $(32.0-39.0)$ & $(35.0-39.0)$ \\
\hline \multirow[t]{2}{*}{2} & $25.3 \pm 0.4^{a}$ & $27.6 \pm 0.5^{b}$ & $32.3 \pm 0.4^{c}$ & $34.71 \pm 0.5^{d}$ & $34.71 \pm 0.5^{d}$ \\
\hline & $(24.0-27.0)$ & $(26.0-30.0)$ & $(30.0-33.0)$ & $(33.0-36.0)$ & $(33.0-36.0)$ \\
\hline \multirow[t]{2}{*}{3} & $25.71 \pm 0.5^{a}$ & $29.43 \pm 0.4^{b}$ & $33.14 \pm 0.5^{c}$ & $35.0 \pm 0.5 d$ & $36.57 \pm 0.5^{\mathrm{e}}$ \\
\hline & $(24.0-27.0)$ & $(28-31.0)$ & $(32.0-35.0)$ & $(33.0-37.0)$ & $(35.0-39.0)$ \\
\hline \multirow[t]{2}{*}{4} & $24.3 \pm 0.5^{a}$ & $28.1 \pm 0.7^{b}$ & $31.6 \pm 0.6^{c}$ & $34.0 \pm 0.3^{d}$ & $34.57 \pm 0.3^{d}$ \\
\hline & $(23.0-26.0)$ & $(25.0-31.0)$ & $(28.0-33.0)$ & $(33.0-35.0)$ & $(33.0-35.0)$ \\
\hline \multirow[t]{2}{*}{5} & $26.3 \pm 0.5^{a}$ & $28.1 \pm 0.8^{b}$ & $31.4 \pm 0.3^{c}$ & $32.6 \pm 0.3^{c}$ & $33.0 \pm 0.5^{c}$ \\
\hline & $(24.0-27.0)$ & $(25.0-31.0)$ & $(30.0-32.0)$ & $(31.0-33.0)$ & $(31-35.0)$ \\
\hline Overall mean \pm SEM & $25.5 \pm 0.5$ & $28.1 \pm 0.6$ & $32.2 \pm 0.5$ & $34.3 \pm 0.5$ & $35.0 \pm 0.5$ \\
\hline Range & 4.0 & 6.0 & 7.0 & 8.0 & 4.0 \\
\hline
\end{tabular}

\section{Table 2}

Temperature-humidity index $\left({ }^{\circ} \mathrm{C}\right)$ in poultry pen during the hot-dry season 


\begin{tabular}{|c|c|c|c|c|c|}
\hline & & h Time, & & & \\
\hline Week & 06:00 & 09:00 & $12: 00$ & $15: 00$ & $18: 00$ \\
\hline \multirow[t]{2}{*}{1} & $25.4 \pm 0.4^{\mathrm{a}}$ & $26.1 \pm 0.3^{\mathrm{a}}$ & $30.6 \pm 0.4^{b}$ & $32.5 \pm 0.7^{c}$ & $33.0 \pm 0.5^{d}$ \\
\hline & $\begin{array}{l}(24.20- \\
26.29)\end{array}$ & $\begin{array}{l}(24.60- \\
26.80)\end{array}$ & $\begin{array}{l}(28.80- \\
31.80)\end{array}$ & $(30.0-35.40)$ & $(31.40-35.0)$ \\
\hline \multicolumn{6}{|l|}{2} \\
\hline & $24.5 \pm 0.3^{\mathrm{a}}$ & $26.4 \pm 0.4^{b}$ & $30.1 \pm 0.4^{c}$ & $32.0 \pm 0.3^{d}$ & $31.8 \pm 0.5 d$ \\
\hline & $\begin{array}{l}(23.20- \\
25.80)\end{array}$ & $(24.80-28.0)$ & $(28.40-31.0)$ & $(31.0-32.80)$ & $\begin{array}{l}(30.20- \\
33.60)\end{array}$ \\
\hline \multirow[t]{2}{*}{3} & $24.6 \pm 0.8^{\mathrm{a}}$ & \multirow{2}{*}{$\begin{array}{l}28.0 \pm \\
1.7^{\mathrm{b}} \\
(27.20- \\
28.40)\end{array}$} & $31.0 \pm 0.4^{c}$ & $33.3 \pm 0.4^{c}$ & $33.2 \pm 0.6^{d}$ \\
\hline & $(22.0-26.60)$ & & $(30.0-32.20)$ & $\begin{array}{l}(30.80- \\
33.40)\end{array}$ & $(31.0-35.40)$ \\
\hline \multirow[t]{2}{*}{4} & $23.1 \pm 0.5^{\mathrm{a}}$ & \multirow{2}{*}{$\begin{array}{l}27.0 \quad \pm \\
0.6^{\mathrm{b}} \\
(24.20-29.0)\end{array}$} & $29.2 \pm 0.4^{c}$ & $31.0 \pm 0.4^{d}$ & $31.7 \pm 0.2^{d}$ \\
\hline & $\begin{array}{l}(21.80- \\
24.80)\end{array}$ & & $\begin{array}{l}(26.80- \\
30.40)\end{array}$ & $\begin{array}{l}(30.20- \\
32.60)\end{array}$ & $\begin{array}{l}(30.80- \\
32.60)\end{array}$ \\
\hline \multicolumn{6}{|l|}{5} \\
\hline & $25.3 \pm 0.5^{a}$ & $27.0 \pm 0.7^{b}$ & $29.5 \pm 0.3^{c}$ & $30.3 \pm 0.2^{d}$ & $30.5 \pm 0.4^{d}$ \\
\hline & $\begin{array}{l}(23.20- \\
26.20)\end{array}$ & $\begin{array}{l}(24.20- \\
29.40)\end{array}$ & $\begin{array}{l}(28.40- \\
30.40)\end{array}$ & $(29.40-31.0)$ & $\begin{array}{l}(28.60- \\
32.20)\end{array}$ \\
\hline \multicolumn{6}{|l|}{6} \\
\hline & $24.6 \pm 0.3^{a}$ & $26.1 \pm 0.3^{b}$ & $28.5 \pm 0.3^{c}$ & $29.3 \pm 0.4^{c}$ & $29.4 \pm 0.3^{d}$ \\
\hline \multirow[t]{2}{*}{$\begin{array}{l}\text { Overall mean } \pm \\
\text { SEM }\end{array}$} & $\begin{array}{l}(23.20- \\
25.20)\end{array}$ & $\begin{array}{l}(24.80- \\
26.80)\end{array}$ & $\begin{array}{l}(26.80- \\
29.40)\end{array}$ & $\begin{array}{l}(27.40- \\
30.20)\end{array}$ & $(28.0-30.60)$ \\
\hline & $24.58 \pm 0.46$ & $26.7 \pm 60.6$ & $29.66 \pm 0.36$ & $31.4 \pm 0.4$ & $31.6 \pm 0.42$ \\
\hline
\end{tabular}


$a, b, c, d=$ Means $( \pm$ SEM $)$ values with different superscript letters $a, b, c, d$ are significantly $(P<0.05)$ different.

*Data in parentheses represent minimum and maximum dry-bulb temperature.

\section{Temperature-humidity index}

The THI value was lowest at 0:600 $\mathrm{h}\left(23.1 \pm 0.05^{\circ} \mathrm{C}\right)$, obtained at the $4^{\text {th }}$ week of the study; while the highest $(P<0.05)$ value $\left(33.3 \pm 0.4^{\circ} \mathrm{C}\right)$ was recorded at the $3^{\text {rd }}$ week. The overall THI value $(28.42 \pm$ $0.42^{\circ} \mathrm{C}$ ) was recorded at 0:600 h, 09:00 h, 12:00 h, 15:00 h and 18:00 h, respectively. The overall pattern of THI increased significantly $(P<0.05)$ with time of the day in the order: 18:00 >15:00 $h>12: 00 \mathrm{~h}>09: 00 \mathrm{~h}$ $>06: 00 \mathrm{~h}$ (Table 2). During the study period, the laying hens panted frequently; most often from 10:00 $\mathrm{h}$ of the day, and the intensity increased remarkably between 12:00 $\mathrm{h}$ and 18:00 $\mathrm{h}$.

\section{Effect of lycopene and vitamin E on hen-day egg production}

Supplemental administration of lycopene and a-tocopherol significantly $(P<0.05)$ increased daily egg production, which resulted in a remarkable weekly egg output, when compared with the controls. Laying hens that received lycopene + vitamin $\mathrm{E}$ had hen-day egg production, ranging from the lowest mean value $(59.0 \pm 1.2 \%)$ to the highest hen-day $(66.57 \pm 1.2 \%)$ during the $4^{\text {th }}$ and $3^{\text {rd }}$ week. The extreme minimum and extreme maximum values in lycopene + vitamin E laying hens were $56.0 \%$ and $72.0 \%$, respectively. The overall mean value of hen-day egg production of $62.7 \pm 1.0 \%$ was obtained (Table 3 ). In laying hens supplemented with vitamin $E$ alone, weekly hen-day egg production ranged between $59.0 \pm 1.9 \%$ and 65.3 $\pm 1.5 \%$ hen-day; and the overall mean hen-day $(62.1 \pm 1.2 \%)$ was not significantly $(P>0.05)$ different from that recorded in lycopene + vitamin E laying hens. The overall mean hen-day for the control laying hens $(56.0 \pm 0.8 \%)$ was the lowest $(P<0.05)$, compared to the value recorded in any of the experimental groups (Table 3).

\section{Table 3}

Weekly hen-day egg production (\%) in laying hens during the hot-dry season ( $\mathrm{n}=100$ per group) 
Layer group

\begin{tabular}{|c|c|c|c|c|}
\hline Week & $L+V E$ & L & VE & CONTROL \\
\hline \multirow[t]{2}{*}{1} & $60.57 \pm 0.7^{a}$ & $59.14 \pm 0.8^{\mathrm{a}}$ & $59.0 \pm 1.9^{a}$ & $57.29 \pm 0.9^{a}$ \\
\hline & $(58.0-68.0) \star$ & $(56.0-61.0)$ & $(52.0-65.0)$ & $(53.0-60.0)$ \\
\hline \multirow[t]{2}{*}{2} & $65.30 \pm 0.6^{a}$ & $62.86 \pm 0.9^{a}$ & $64.43 \pm 1.2^{\mathrm{a}}$ & $56.70 \pm 0.7^{b}$ \\
\hline & $(63.0-68.0)$ & $(59.0-66.0)$ & $(61.0-70.0)$ & $(54.0-59.0)$ \\
\hline \multirow[t]{2}{*}{3} & $66.7 \pm 1.5^{\mathrm{a}}$ & $65.10 \pm 1.3^{\mathrm{a}}$ & $65.3 \pm 1.5^{\mathrm{a}}$ & $55.14 \pm 0.5^{b}$ \\
\hline & $(62.0-72.0)$ & $(60.0-69.0)$ & $(58.0-70.0)$ & $(53.0-57.0)$ \\
\hline \multirow[t]{2}{*}{4} & $59.0 \pm 1.2^{\mathrm{a}}$ & $62.40 \pm 1.0^{\mathrm{a}}$ & $59.43 \pm 1.0^{a}$ & $52.8 \pm 0.6^{b}$ \\
\hline & $(56.0-65.0)$ & $(59.0-66.0)$ & $(56.0-62.0)$ & $(50.0-55.0)$ \\
\hline \multirow[t]{2}{*}{5} & $64.30 \pm 0.9^{a}$ & $63.30 \pm 0.7^{a}$ & $61.71 \pm 0.9^{a}$ & $57.0 \pm 1.2^{b}$ \\
\hline & $(62.0-67.0)$ & $(60.0-65.0)$ & $(60.0-65.0)$ & $(53.0-60.0)$ \\
\hline \multirow[t]{2}{*}{6} & $60.60 \pm 0.8^{a}$ & $61.30 \pm 1.6^{\mathrm{a}}$ & $59.90 \pm 0.7^{a}$ & $56.71 \pm 1.1^{\mathrm{b}}$ \\
\hline & $(58.0-63.0)$ & $(54.0-65.0)$ & $(57.0-62.0)$ & $(52.0-60.0)$ \\
\hline Overall mean \pm SEM & $62.7 \pm 1.0$ & $62.4 \pm 1.1$ & $62.1 \pm 1.2$ & $56.0 \pm 0.8$ \\
\hline \multirow[t]{2}{*}{ Range } & $(56.0-72.0)$ & $(54.0-69.0)$ & $(52.0-70.0)$ & $(50.0-60.0)$ \\
\hline & 16.0 & 15.0 & 18.0 & 10.0 \\
\hline
\end{tabular}

$a, b=$ Means $( \pm$ SEM) with different superscript $a$ and $b$ between layer groups are significantly $(P<$ $0.05)$ different.

Data in parentheses represent minimum and maximum hen-day egg production.

$\mathrm{L}+\mathrm{VE}=$ lycopene + vitamin $\mathrm{E}, \mathrm{L}=$ lycopene only, $\mathrm{E}=$ vitamin $\mathrm{E}$ only and CONT = control. 


\section{Relationship ( $r$ ) between temperature-humidity index and hen-day egg production}

The relationship between THI and hen-day egg production was positive in most of the weeks of recordings, particularly in vitamin E group, followed by the lycopene group (Table 4).

\section{Table 4}

Correlation co-efficients between temperature-humidity index and hen-day egg production during the hotdry season

\begin{tabular}{|c|c|c|c|c|}
\hline \multicolumn{5}{|c|}{ Laying hen group } \\
\hline Week & $L+V E$ & $\mathrm{~L}$ & VE & CONT. \\
\hline 1 & 0.022 & -0.029 & $0.513^{\star}$ & $0.580^{\star}$ \\
\hline 2 & -0.226 & 0.921 *** & $0.622^{\star}$ & 0.083 \\
\hline 3 & $0.523^{\star}$ & 0.164 & $0.600 *$ & -0.097 \\
\hline 4 & $0.587^{\star}$ & 0.300 & 0.260 & 0.060 \\
\hline 5 & 0.124 & $0.570^{*}$ & $0.500 *$ & $0.803^{\star \star}$ \\
\hline 6 & $0.580 *$ & $0.609 *$ & $0.760 *$ & $0.613^{*}$ \\
\hline \multicolumn{5}{|c|}{ Correlation values with superscript * are significant $(\mathrm{P}<0.05) ; *=\mathrm{P}<0.01, * \star *=\mathrm{P}<0.001$} \\
\hline \multicolumn{5}{|c|}{$\begin{array}{l}\mathrm{L}+\mathrm{VE}=\text { lycopene }+ \text { vitamin } \mathrm{E} \text {-administered hens; } \mathrm{L}=\text { lycopene-administered hens; } \mathrm{VE}=\text { vitamin } \mathrm{E}- \\
\text { administered hens; } \mathrm{CONT}=\text { control hens. }\end{array}$} \\
\hline
\end{tabular}

\section{Effect of lycopene and vitamin E on eggshell diameter}

The eggshell diameters (thickness) of the laying hens during the hot-dry season are presented in Table 5. Eggshell thickness was the lowest $(P<0.05)$ in control laying hens, compared to all other groups. Overall, eggshell thickness was highest in lycopene + vitamin $\mathrm{E}$ group $(0.28 \pm 0.02 \mathrm{~mm})$. The laying hens administered with vitamin $E$ alone had the thickness of $0.22 \pm 0.02 \mathrm{~mm}$, which did not differ from that of control birds $(0.18 \pm 0.02 \mathrm{~mm})$, but was significantly $(P<0.05)$ lower than the values for the rest of the groups (Figure 1). 
Eggshell diameter ( $\mathrm{mm}$ ) in ISA Brown laying hens administered with lycopene and vitamin E during the hot-dry season (mean \pm SEM; $n=10$ per group)

\begin{tabular}{|c|c|c|c|c|c|}
\hline \multicolumn{6}{|c|}{ Week } \\
\hline Group & 1 & 2 & 3 & 4 & 5 \\
\hline$L+V E$ & $0.33 \pm 0.02^{a}$ & $0.25 \pm 0.01^{\mathrm{a}}$ & $0.30 \pm 0.03^{a}$ & $0.30 \pm 0.02^{\mathrm{a}}$ & $0.24 \pm 0.03^{a}$ \\
\hline L & $0.24 \pm 0.02^{b}$ & $0.26 \pm 0.02^{\mathrm{a}}$ & $0.23 \pm 0.03^{b}$ & $0.32 \pm 0.01^{a}$ & $0.23 \pm 0.03^{a}$ \\
\hline VE & $0.22 \pm 0.03^{b}$ & $0.23 \pm 0.02^{\mathrm{a}}$ & $0.20 \pm 0.02^{b}$ & $0.24 \pm 0.02^{b}$ & $0.20 \pm 0.02^{\mathrm{a}}$ \\
\hline CONT & $0.23 \pm 0.02^{b}$ & $0.19 \pm 0.02^{b}$ & $0.12 \pm 0.02^{c}$ & $0.21 \pm 0.01^{\mathrm{b}}$ & $0.16 \pm 0.02^{b}$ \\
\hline \multicolumn{6}{|c|}{$\begin{array}{l}\text { a, b, } c=\text { Values with different superscript letters between layer groups are significantly }(P<0.05) \\
\text { different. }\end{array}$} \\
\hline \multicolumn{6}{|c|}{$\begin{array}{l}\mathrm{L}+\mathrm{VE}=\text { lycopene + vitamin E-administered hens; } \mathrm{L}=\text { lycopene-administered hens; } \mathrm{VE}=\text { vitamin } \mathrm{E}- \\
\text { administered hens; } \mathrm{CONT}=\text { control hens. }\end{array}$} \\
\hline
\end{tabular}

\section{Effect of lycopene and vitamin E on eggshell weight}

The result showed that the control laying hens recorded the least overall eggshell weight $(6.7 \pm 0.02 \mathrm{~g})$; which was significantly $(P<0.05)$ lower than the values recorded in lycopene + vitamin $E$, lycopene and vitamin E groups $(7.3 \pm 0.24 \mathrm{~g}, 7.3 \pm 0.3 \mathrm{~g}$ and $7.2 \pm 0.3 \mathrm{~g}$ respectively) (Table 6 and Figure 2 ).

Table 6

Eggshell weight $(\mathrm{g})$ of ISA Brown laying hens administered with lycopene and vitamin E during the hot-dry season (mean \pm SEM; $n=10$ per group) 


\begin{tabular}{|c|c|c|c|c|c|}
\hline \multicolumn{6}{|c|}{ Week } \\
\hline Group & 1 & 2 & 3 & 4 & 5 \\
\hline \multicolumn{6}{|l|}{$L+V E$} \\
\hline & $7.4 \pm 0.3$ & $7.0 \pm 0.3$ & $7.4 \pm 0.2$ & $7.5 \pm 0.2^{a}$ & $7.1 \pm 0.2^{a}$ \\
\hline \multicolumn{6}{|l|}{$\mathrm{L}$} \\
\hline & $7.2 \pm 0.2$ & $7.6 \pm 0.3$ & $7.5 \pm 0.3$ & $7.1 \pm 0.2$ & $7.0 \pm 0.5^{\mathrm{a}}$ \\
\hline \multicolumn{6}{|l|}{ VE } \\
\hline & $7.0 \pm 0.3$ & $7.7 \pm 0.2$ & $7.2 \pm 0.4)$ & $7.7 \pm 0.3$ & $6.6 \pm 0.3^{b}$ \\
\hline \multicolumn{6}{|l|}{ CONT } \\
\hline & $7.0 \pm 0.3$ & $6.3 \pm 0.2^{b}$ & $7.1 \pm 0.2$ & $6.5 \pm 0.2^{b}$ & $6.5 \pm 0.2^{b}$ \\
\hline \multicolumn{6}{|c|}{$\begin{array}{l}\text { a, b, c = Values with different superscript letters between hen groups are significantly }(P<0.05) \\
\text { different. }\end{array}$} \\
\hline \multicolumn{6}{|c|}{$\begin{array}{l}\mathrm{L}+\mathrm{VE}=\text { lycopene }+ \text { vitamin E-administered birds; } \mathrm{L}=\text { lycopene-administered birds; } \mathrm{VE}=\text { vitamin } \mathrm{E}- \\
\text { administered layers; CONT = control layers. }\end{array}$} \\
\hline
\end{tabular}

\section{Discussion}

The results show that during the hot-dry season, the afternoon and evening hours were most thermally stressful to the laying hens. The ambient temperatures and correspondingly the heat load rose progressively from daily nadirs (minimum) at early hours of the day, beginning from 06:00 $\mathrm{h}$ and attaining the peak (maximum) at the end of the day, at 18:00 h. Diurnal variations show that the overriding environmental factor affecting the hens was the ambient temperature. The finding was similar to the reports of Vathana et al. (2002), Ayo et al. (2007) and Minka and Ayo (2010) that ambient temperature is characterised by diurnal variations and it is the principal determinant of the metabolic parameters. The recorded trend in environmental temperature was similar to that obtained during the hotdry season by Dzenda et al. $(2013,2015)$ that heat stress is prevalent throughout the day in the zone. Thus, the hot-dry season in the zone may be thermally stressful to poultry, starting from the early hours of the day, at the rising of the sun, to the end of daylight.

The upper limit of DBT $\left(36.71 \pm 0.6^{\circ} \mathrm{C}\right)$, which ranging from $35.0-39.0^{\circ} \mathrm{C}$ and recorded at $18: 00 \mathrm{~h}$, corresponded to a $\mathrm{THI}$ of $33.0^{\circ} \mathrm{C}\left(31.40-35^{\circ} \mathrm{C}\right)$ shows that the value was remarkably higher than the DBT upper limit of 24 or $26^{\circ} \mathrm{C}$ of the thermoneutral (comfort) zone for poultry in the temperate environment 
(Holik, 2009; Kingori, 2011). The value was also outside the range of $18-26^{\circ} \mathrm{C}$, reported for poultry, reared under tropical environmental conditions (Ayo et al. 2010; Oluyemi and Roberts 2000; Fernandes et al. 2013). At $6: 00 \mathrm{~h}$ the lowest $\mathrm{DBT}$ of $24.3 \pm 0.5^{\circ} \mathrm{C}$, corresponding to $\mathrm{THI}$ of $23.1^{\circ} \mathrm{C}$ fell within the range of the upper limit reported for poultry, and it was the only DBT value recorded that was strictly within the comfort (thermoneutral) zone (Tables 2 and 3). Thus, the laying hens during the hot-dry season in the zone were reared under the DBT values that were predominantly outside the thermoneutral (comfort) zone, indicating that the thermoregulatory mechanisms of the laying hens may be overtasked to near exhaustion in an attempt to ensure homeothermy (Altan et al. 2003; Minka and Ayo (2010). Such impairment results in a down-turn in physiological and performance parameters of the laying hens, indicating that the ambient temperature may have negative influence on the well-being and productivity of the laying hens (Ayo et al. 2011; Leinonen et al. 2014b).

The heat stress observed from the study period corroborates the reports of Ayo et al. (2007), Aluwong et al. (2017) and Makeri et al. (2017), who demonstrated the prevalence of heat stress in the zone during the hot-dry season. Oladele et al. (2003) reported the deterrent effects of heat stress on biochemical parameters in avian species in the zone, and Ayo et al. (2014a) documented some detrimental effects of heat stress on CT and performance parameters of pullets in the zone.

The present study showed that high ambient temperatures are inimical to egg production and supports the reports of Felva-Grant et al. (2012) and Leinonen et al. (2014), who demonstrated that high ambient temperature is a deterrent on fecundity in poultry. Obidi et al. $(2008 \mathrm{a}, \mathrm{b})$ have demonstrated the deleterious effects of the hot-dry season on fertility and hatchability in breeder hens, and that the season depresses sperm concentration, motility and fertility in breeder cocks in the zone.

Panting recorded shortly after 9:00 $\mathrm{h}$ was heightened between $15: 00 \mathrm{~h}$ and 18:00 $\mathrm{h}$ of the day due to sustained heat load. In some cases during the study, the laying hens were visibly going-off their feeders and concentrating activity around the drinkers, where they were observed to drink more intensively and rested under their feed augers. The observations corroborate the findings of Minka and Ayo (2010) and Mack et al. $(2010,2013)$, who reported stressful behavioural responses in birds exposed to heat stress.

The present study has shown that high ambient temperature, resulting in increase in thermal load in poultry, induced panting which is an indication of behavioural thermoregulation in the laying hens (FelverGant et al. 2012). Such behavioural response in domestic birds to heat stress has been reported by Mack et al. $(2010,2013)$, who demonstrated that laying hens subjected to heat stress spend less time feeding, but more time drinking and panting. They also spend more time with their wings elevated, less time moving or walking, and more time resting.

The results of the present study show that supplemental co-administration or individual inclusion of lycopene and vitamin E significantly supported fecundity in hens during the hot-dry season in the zone, when heat stress was prevalent. Similar results were obtained by Sahin et al. (2002), Olson et al. (2008) and Turk et al. (2010), who demonstrated that lycopene and vitamin E enhance ovarian function during heat stress. Although there was no significant difference between the treatment groups, antioxidant- 
administered laying hens recorded a relatively hen-day egg production than the control hens. The result, for the first time, has provided evidence on the beneficial role of the carotenoid lycopene and a-tocopherol in ovarian function in avian fertility in the zone. Few studies have demonstrated the significant potential of lycopene in enhancing immunity and reproductive efficiency in poultry (Olson et al. 2008; Turk et al. 2010). The co-supplementation of lycopene and vitamin E to laying hens during the hot-dry season resulted in the highest hen-day egg production throughout the experimental period. The result shows that lycopene- and/or a-tocopherol-treated laying hens maintained consistently hen-day production, amounting to over $6 \%$ weekly mean egg production, compared with the controls.

The the rate of decline in hen-day egg production was mitigated in lycopene- and vitamin E-administered laying hens in comparison with the control hens. This was, apparently, irrespective of the deterrent associated with old age of the laying hens and the thermal load acting on them during the hot-dry season. This finding supports the previous report on the antioxidant and/or antistress activities of vitamin E and corroborated by Vazquez et al. (2018), Lewis et al. (2019) and Liu et al. (2019), who reported the antistress and antiinflammatory effects of vitamin $E$ in hens exposed to heat stress-induced conditions. Olson et al. (2008) and Yardibi and Turkay (2008) demonstrated the ameliorative effects of vitamin $\mathrm{E}$ on egg production, egg quality and nutrient utilisation in laying hens exposed to heat stress, thereby improving fertility and fecundity. The present study was conducted on laying hens, aged 41 weeks at the beginning of the study, when vital indices of fertility, including the rate of egg production and quality in hens normally start to decline due to age-related gonadal dysfunction and metabolic alterations, mediated by oxidative stress (Surai et al. 2001; Romero-Sanchez et al. 2007; Surai 2009). Such age-related ovarian functional depreciation is significantly associated with stress-mediated compromise in mitochondrial function due to the susceptibility of the ovarian structural lipoproteins to oxidative stress (Burstein et al. 2009; Bentov et al. 2014; Ben-Meir et al. 2015).

The result shows that lycopene ameliorated the effect of heat stress on laying hens and improved henday egg production. Although the mechanism of action of lycopene was not elucidated in the present study, the reports of Sahin et al. (2002) and Yardibi and Turkay (2008) demonstrated lycopene's antioxidant activity in avian species and its beneficial biological intervention in stress-induced ovarian failure. Bakker et al. (2010) showed the anti-inflammatory and antioxidative roles of a dietary mixture of vitamin E and lycopene. Since most physiological anomalies, including disease conditions and reproductive (gonadal) dysfunctions, are mediated by inflammatory and oxidative stress mechanisms, the findings of the present study on lycopene and a-tocopherol in alleviating heat-induced stress and reproductive losses during the hot-dry season may also be due to their anti-inflamatory and antioxidative properties (Liu et al. 2019; Pitargue et al. 2019).

The remarkable decrease in eggshell thickness and eggshell weight in control laying hens, suggests a decrease in calcium mobilisation and utilisation during the heat stress. The results corroborate previous reports (Lin et al. 2004; Periera et al. 2008; Melesse et al. 2010; Mack et al. 2013) that heat-induced stress adversely affects qualitative indices of eggshell in laying hens. Eggshell quality is an important index of overall egg quality, associated with the efficiency of calcium mobilisation and deposition on eggshell in

Page $14 / 22$ 
the process of egg formation. This physiological aptitude of the laying hens reduces during unfavuorable conditions, including excessive increase in environmental temperatures (Hafeez et al. 2016; Lee and Han, 2018; Klasing and Korver, 2020). The results show that lycopene and vitamin E ameliorated the deleterious effects of heat stress on the laying hens in the zone, which suggests that the antioxidants may improve qualitative indices of the egg in the laying hens, exposed to environmental heat stress in the hot-dry season in the zone. The observation supports the reports of Olson et al. (2008) and Sahin et al. $(2008,2016)$ that lycopene supplementation alleviates heat-induced stress on performance parameters of domestic birds, including egg qualitative indices. Similar report by Scheideler et al. (2010) demonstrated the beneficial effect of vitamin E on egg production, qualitative eggshell indices and integrity in breeder hens, subjected to high ambient temperature. The combined effect of vitamin $E$ and lycopene in alleviation of stress indices in domestic chickens exposed to high oxidant conditions has been demonstrated by Lu et al. (2014).

In conclusion, thermal environment conditions during the hot-dry season in the Northern Guinea Savannah zone induced heat stress, adversely affecting domestic laying hens. The thermal environmental conditions exerted negative effects on the laying hens via impairment in egg qualitative indices. Lycopene and vitamin E alleviated the risk of adverse effects of heat stress on their productivity during the hot-dry season by increasing hen-day egg production and improving eggshell qualitative indices.

\section{Declarations}

Funding

No funding was received for this research

\section{Conflicts of interest}

There is no conflict of interest.

\section{Availability of data and materials}

Data was obtained from the research and can be made available on request

\section{Code availability}

Not applicable

\section{Authors contributions}


Joseph Ayodele Obidi: Analyzed data, wrote the paper

Joseph Olusegun Ayo : Designed the study, Analyzed data, wrote the paper

Peter Ibrahim Rekwot: Supervision and Editing

Barth Izuchukwu Onyeanusi: Supervision and Editing

\section{Ethics approval}

The husbandry and the conduct of the experiments on the laying hens were performed in accordance with the European Convention for the Protection of Vertebrate Animals used for Experimental and other Scientific Purposes (Council of Europe No 123, Strasbourg 1985). All the experimental protocols described were approved by the Ethics Review Committee for Animal Experimentation of Ahmadu Bello University, Zaria, Nigeria.

\section{Consent to participate}

None of the authors that participated in the research was coerced.

\section{Consent for publication}

All authors have approved the research for publication.

\section{References}

1. Aluwong, T., Sumanu, V. O., Ayo, J. O., Ocheja, Benjamin O., Zakari, F. O., Minka, Ndazo S., 2017. Daily rhythms of cloacal temperature in broiler chickens of different age groups administered with zinc gluconate and probiotic during the hot-dry season. Physiol. Reports. ISSN 2051-817X.

2. Attia Y. A., Hassan R.A, Tag El-Din A. E., Abou-Shehema B. M. 2011. Effect of ascorbic acid or increasing metabolisable energy level with or without supplementation of some essential amino acids on productive and physiological traits of slow-growing chicks exposed to chronic heat stress.J. Anim. Physiol. Anim. Nutr.95:744-755.

3. Ayo, J. 0., Owoyele, O. O., Dzenda, T., 2007. Effects of ascorbic acid on diurnal variations in rectal temperature of Bovan Nera pullets during the harmattan season. Inter. J. Poult. Sci. 6(8): 612-616.

4. Ayo, J.O.,Obidi, J.A., Rekwot, P. I., 2011. Effects of heat stress on the well-being, fertility and hatchability of domestic chickens in the Northern Guinea Savannah zone of Nigeria: a review. International Scholarly Res. Network Vet. Sci. 2011, doi: 10.5402/2011/ 838606.

5. Ayo, J.O., Danbirinin, S., Egbuniwe, I. C., Sinkalu, V.O., 2014a. Cloacal temperature responses and some performance indices in Black Harco pullets administered with betaine during the hot-dry 
season. J. Vet. Sci. Tech. 5: 2. Doi: 10: ${ }^{4172 / 2157-7570.1000166 . ~}$

6. Ayo, J.O., Egbuniwe, I., Kawu, M., Sinkalu, V. O., 2014b. Ameliorative effects of betaine and ascorbic acid administration to broiler chickens during the hot-dry season in Zaria: A review. African J. Biotech.13 (23): 2295-2306.

7. Altan, O., Pabuçcuoğlu, A., Altan, A., Konyalioğlu, S.' Bayraktar, H., 2003. Effect of heat stress on oxidative stress, lipid peroxidation and some stress parameters in broilers.British Poult Sci.44(4):545550.

8. Ben-Meir, A., Burstein, E., Alvarez, A. B.., Chong, J., Wong, E., Yavorska, T., Naranian, T., Chi, M., Wang, Y., Bentov, Y., Alexis, J., Meriano, J., Sung, H.. Gasser, D. L., Moley, K. H., Hekimi, S., Casper, R. F., Jurisicova, A., 2015. Coenzyme Q10 restores oocyte mitochondrial function and fertility during reproductive ageing. Ageing Cell. 14: 887-895

9. Bentov, Y., Yavorska T., Esfandiari N., Jurisicova, A. Casper R. F., 2011. The contribution of mitochondrial function to reproductive aging. J. Assist. Reprod. Genetics.28: 773-783.

10. Boileau, T.W.-M., Boileau, A. C., Erdman Jr, J. W., 2002. Bioavailability of all-trans and cis-isomers of lycopene. Exp.. Biol. Med. 227: 914-919.

11. Boileau, T.W. M., Liao, Z., Kim, S., Lemeshow, S., Edman Jr, J. W., Clinton, S. K., 2003. Prostate carcinogenesis in $\mathrm{N}$-methyl-nitrosourea-testosterone-treated rats fed tomato powder, lycopene or energy-restricted diets. J. National Cancer Instit. 95: 1578-1586.

12. Burstein, E., Perumalsamy, A., Bentov, Y., Esfandiari, N., Jurisicova, A., Casper, R. F., 2009. Co-enzyme Q10 supplementation improves ovarian response and mitochondrial function in aged mice.Fertil. Steril.92(3) (Suppl. 1): S31.

13. Dzenda, T., Ayo, J. O., Lakpini, C. A. M. Adelaiye, A. B. M., 2013. Season, sex and live weight variations in feed and water consumption of adult captive African giant rat (Cricetomys Gambianus, Waterhouse-1840) kept individually in cages. J. Anim. Physiol.Anim. Nutri. 97: 465-474.

14. Dzenda, T.,Ayo, J. O.,Sinkalu, V. O.,Yaqub, L. S., 2015. Diurnal, seasonal, and sex patterns of heart rate in grip-restrained African Giant rats (Cricetomys gambianus, Waterhouse). Physiol. Reports.3(10): e12581.

15. Felver-Gant, J. N., Mack, L. A., Dennis, R. L., Eicher, S. D., Cheng, H. W., 2012.Genetic variations alter physiological responses following heat stress in 2 strains of laying hens.Poult. Sci. 91: 1542 - 1551.

16. Fernandes, J. M., Scapini, L. B., Gottardro, E. T., Burin Jr, A. B., Marques, F. E., Gruchouskei, L., 2013. Thermal conditioning during the first week on performance, heart morphology and carcass yield of broilers submitted to heat stress. Acta Sci. 35: 311-313.

17. Hafeez, A., Mader, A., Ruhnke, I., Manner, K. and Zentek, J. (2016). Effect of feed grinding methods with and without expansion on prececal and total tract mineral digestibility as well as on interior and exterior egg quality in laying hens. Poult. Sci. 95: 62-69.

18. Helmy, M. M., Senbel, A. M., 2012. Evaluation of vitamin E in the treatment of erectile dysfunction in aged rats. Life Sci, 90: 489-494. 
19. Holik, V., 2009. Management of laying hens to minimize heat stress. Lohmann Info. 44: 16-29.

20. Imik H., Ozlu H., Gumus R., Atasever M. A., Urgar S., Atasever, M., 2012. Effects of ascorbic acid and alpha-lipoic acid on performance and meat quality of broilers subjected to heat stress.British Poult. Sci.53: 800 -808.

21. Kelso, K. A., Cerolini, S., Noble, R. C., Sparks, N.H. C., Speake, B. K., 1996. Lipid and antioxidant changes in semen of broiler fowl from 25 to 60 weeks of age. J. Reprod. Fertil. 106: 210 - 206.

22. Khan, N., Afaq, F., Mukhtar, H., 2008. Cancer chemoprevention through dietary antioxidants: Progress and promise. Antioxid. Redox Signal. 10(3): doi:10.1089/ars.2007.1740.

23. Kinggori, A. M., 2011. Review of factors that influence egg fertility and hatchability in poultry. Inter. J. Poult. Sci. 10: 16-29.

24. Klasing, K. C., Korver D. R.. 2020. Nutritional diseases. (In Diseases of Poultry. D. E. Swayne, ed. 14th ed.) Wiley-Blackwell, Hoboken, NJ, Pp. 1257-1285

25. Lee, G. Y., Han. S. N., 2018. The role of vitamin E in immunity. Nutrients. 10: 1614.

26. Leinonen, I., Williams, A. G., Kyriazakis, I., 2014.The effects of welfare-enhancing system changes on the environmental impacts of broiler and egg production.Poult. Sci. 93: 256-266.

27. Lewis, E. D., S. N. Meydani, Wu, D., 2019. Regulatory role of vitamin E in the immune system and inflammation. IUBMB Life 71: 487-494.

28. Lin, H., Mertens, K., Kemps, B., Govaerts, T., De Ketelaere, B., De Baerdemaeker, J., Decuypere, E., Buyse, J. 2004. New approach of testing the effect of heat stress on eggshell quality: Mechanical and material properties of eggshell and membrane. British Poult. Sci. 45: 476-482.

29. Liu, Y. J., L. H. Zhao, R. Mosenthin, J. Y. Zhang, C. Ji, Ma, Q. G. 2019. Protective effect of vitamin E on laying performance, antioxidant capacity, and immunity in laying hens challenged with Salmonella enteritidis. Poult. Sci. 98: 5847-5854.

30. Lu, T., Harper, A. F., Zhao, J. and Dalloul, R. A. (2014). Effects of a dietary antioxidant blend and vitamin $\mathrm{E}$ on growth performance, oxidative status, and meat quality in broiler chickens fed a diet high in oxidants. Poult. Sci. 93: 1649 -1657.

31. Mack, L. A., Felver-Gant, J. N., Dennis, R. L., Cheng. H. W., 2010. Effects of heat stress on egg production and quality in two strains of laying hens. Poult. Sci. 87: (Suppl.) 120.

32. Mack L.A., Felver-Gant J. N., Dennis R. L., Cheng H. W.,2013. Genetic variation alter production and behavioural responses following heat stress in 2 strains of laying hens.Poult. Sci. 92: 285-294.

33. Marketon, J. I. W., Glaser, R., 2008. Stress hormones and immune function.Cellular Immunol.252:1626.

34. Melesse, A., Maak, S., von Lengerken, K., 2010. Effect of long-term heat stress on egg quality traits of Ethiopian naked neck chickens and their F1 crosses with Lohmann White and New Hampshire chicken breeds. Livest. Res. Rural Devt. 22. Accessed Apr. 2018.http://www.Irrd.org/Irrd22/4/ mele22071.htm. 
35. Minka, N. S., A yo, J.O., 2010. Behavioural and rectal temperature responses of Black Harco pullets administered vitamins $\mathrm{C}$ and $\mathrm{E}$ and transported by road during the hot-dry season. J. Vet. Behav. 5: $134-144$.

36. Mirfenereski, E., Johannian, R., 2015.Effects of dietary organic chromium and vitamin C supplementation on performance, immune responses, blood metabolites, and stress status of laying hens subjected to high stocking density.Poult. Sci. 94: 281-288.

37. Obidi, J. A., Onyeanusi, B. I., Rekwot, P. I. Ayo, J. O., Dzenda, T., (2008a). Seasonal variations in seminal characteristics of Shikabrown breeder cocks. Intern. J. Poult. Sci. 7 (12): 1219 -1223.

38. Obidi, J. A., Onyeanusi, B. I., Ayo, J. O., Rekwot, P. I., Abdullahi, S. J., 2008b. Effect of timing of artificial insemination on fertility and hatchability of Shikabrown breeder hens. Intern. J. Poult. Sci. 7(12): 1224-1226.

39. Opoku, E. Y., Classen, H. L. Scott, T. A., 2015. Effects of wheat distillers dried grains with solubles with or without protease and $\beta$-mannanase on the performance of turkey hen poults.Poult. Sci.94 (2): 207214.

40. Oladele, S. B., Ogundipe, S., Ayo, J. O., Esievo, K. A. N. 2003. Seasonal and species variations in erythrocyte osmotic fragility of indigeneous poultry species in Zaria, Northern Guinea Savannah zone of Nigeria. Bull. Anim. Health Prod. Africa. 51: 204-214.

41. Oluyemi, J.A., Roberts, P. A., 2000. Poultry Production in the Warm Wet Climates. Spectrum Book Limited, Ibadan, Nigeria, Pp: 103-108.

42. Olson, J.B., Ward, N. E., Koutsos, E. A., 2008. Lycopene incorporation into egg yolk and effects on the laying hen's immune function. Poult. Sci. 87: 2575-2580.

43. Palozza, P., Catalano, A., Simone, R., Cittadini, A. 2012. Lycopene as a guardian of redox signaling. Acta Biochemica Polonica, 59 (1): 21-25.

44. Pereira, D. F., G. Vitorasso, S. C. Oliveira, S. K. Kakimoto, C. K. Togashi, Soares, N. M., 2008. Correlations between thermal environment and egg quality of two layer commercial strains. Brazilian J. Poult. Sci. 10: 81- 88.

45. Pitargue, F. M., J. H. Kim, D. Goo, J. B., Delos Reyes, Kil, D. Y.. 2019. Effect of vitamin E sources and inclusion levels in diets on growth performance, meat quality, alpha-tocopherol retention, and intestinal inflammatory cytokine expression in broiler chickens. Poult. Sci. 98: 4584 - 4594.

46. Quinteiro-Filho, W. M., Ribeiro, A., Ferraz-de-Paula, V., Pinheiro, M. L., Sakai, M., Sa, L. R. M., Ferreira, A. J. P., Palermo-Neto, J., 2010. Heat stress impairs performance parameters, induces intestinal injury, and decreases macrophage activity in broiler chickens.Poult. Sci. 89: 1905-1914.

47. Romero-Sanchez, H., Plumstead, H., Brake, J. 2007. Feeding broiler breeder males. 1. Effect of feeding program and dietary crude protein during rearing on body weight and fertility of broiler breeder males. Poult. Sci. 86 (1):168-174.

48. Rozenboim, I., Mobarky, N., Heiblum, R., Chaiseha, Y., Kang, S.W., Biran, I., Rosenstrauch, A., Sklan, D., El Halawani, M. E., 2004. The role of prolactin in reproductive failure associated with heat stress in the domestic turkey. Biol. Reprod. 71: 1208-1213. 
49. Sahin, K., Sahin, N., Onderci, M., 2002. Vitamin E supplementation can alleviate negative effects of heat stress on egg production, egg quality, digestibility of nutrients and egg yolk mineral concentrations of Japanese quails. Res. Vet. Sci. 73: 307-312.

50. Sahin, N., Orhan, C., Tuzcu, M., Sahin, K. and Kucuk, O. (2008). The effects of tomato powder supplementation on performance and lipid peroxidation in quail. Poultry Science, 87: 276 -283.

51. Sahin, K.,Orhan, C., Tuzcu, M., Sahin, N., Hayirli, A., Bilgili, S., Kucuk, O.,2016. Lycopene activates antioxidant enzymes and nuclear transcription factor systems in heat-stressed broilers. Poult Sci. 1088-1095.

52. Scheideler, S. E., Weber, P., Monsalve, D., 2010. Supplemental vitamin E and selenium effects on egg production, egg quality, and egg deposition of a-tocopherol and selenium. J.Appl.Poult. Res. 19: 354 360 .

53. Star, L., Kemp, B., van den Anker, I., Parmentier, H. K. 2008a. Effect of single or combined climatic and hygienic stress in four Layer Lines: 1. Performance. Poult. Sci., 87: 1022-1030.

54. Star, L., Decuypere, E., Parmentier, H. K., Kemp, B., 2008b. Effect of single or combined climatic and hygienic stress in four layer lines: 2. Endocrine and oxidative stress responses. Poult. Sci. 87: 10311038.

55. Sun, B., Chen, C., Wang, W., Ma, J., Xie, Q., Gao, Y., Chen, F., Zhang, X. Bi, Y., 2014. Effects of lycopene supplementation in both maternal and offspring diets on growth performance, antioxidant capacity and biochemical parameters in chicks. J. Anim. Physiol. Nutri. Doi: 1111/jpn.12196.

56. Surai, P. F., Fujihara, N., Speake, B. K., Brillard, J. P., Wishart, G. J., Sparks, H. N. C., 2001.

Polyunsaturated fatty acids, lipid peroxidation and antioxidant protection in avian species- review. Asian-Austral. J. Anim. Sci.14 (7): 1024-1050.

57. Surai, P. F., 2009. Natural antioxidants in poultry nutrition: new developments. $16^{\text {th }}$ European Symposi. Poult. Nutri.. Pp 669-676.

58. Surai, P. F., 2020. Antioxidants in poultry nutrition and reproduction: An update.Antioxid. 9(105): Doi10.3390/antiox9020105.

59. Surai, P. F., Kochish, I. I., Romanov, M. N., Griffin, D. K., 2019. Nutritional modulation of the antioxidant capacities in poultry: the case of vitamin E. Poult. Sci. 98: 4030-4041.

60. Turk, G., Ceribasi, A. O., Sakin, F., Sonmonz, M. Atessahin, A. 2010. Antiperoxidative and anti-apototic effects of lycopene and ellagic acid on cyclophosphamide-induced testicular lipid peroxidation and apoptosis. Reprod. Fertil. Devt. 22: 587-596.

61. Troxell, B., 2016. Salmonella enterica serovar Typhimurium utilizes the ClpPX and Lon proteases for optimal fitness in the caeca of chickens. Poult. Sci. 95: 1617-1623.

62. Urso, U. R. A.,Dahlke, F.,Maiorka, A., Bueno, I. J. M., Schneider, A. F.,Surek, D., Rocha, C.2015. Vitamin E and selenium in broiler breeder diets: Effect on live performance, hatching process, and chick quality. Poult. Sci. 94: 976 - 983. 
63. Vathana, S., Kang, K., Loan, C.P., Thinggaard, G., Kabasa, J.D., ter Meulen, U., 2002. Effect of vitamin C supplementation on performance of broiler chickens in Cambodia. Proc. Inter. Conf. Agric. Res. Devt. Witzenhausen: Deutcher Tropentag.

64. Vazquez, J. R., G. V. G_omez, C. C. L_opez, A. C. Cort_es, A. C. Díaz, S. R. T. Fern_andez, E. M. Rosales, Avila, A. G., 2018. Effects of 25-hydroxycholecalciferol with two D3 vitamin levels on production and immunity parameters in broiler chickens. J. Anim. Physiol. Anim. Nutr. (Berl). 102:e493-e497.

65. Wang, Y., Chung, S., Marjorie, L., McCullough, Won O. S., Fernandez, M. L., Koo, Sung, I., Chun, Ock, K., 2014. Dietary carotenoids are associated with cardiovascular disease risk biomarkers mediated by serum carotenoid concentrations.J. Nutri.144: 1067-1074.

66. Wertz, K., Siler, U., Goralczyk, R., 2004. Lycopene: Modes of action to promote prostate health. Arch. Biochem. Biophy. 430: 127-134.

67. Wu, K., Schwartz, S. J., Platz, E. A., Clinton, S. K., Erdman, J. W., Ferruzzi, M. G., 2003. Variations in plasma lycopene and isomers over time in cohort of US men. J. Nutri. 133: 1930-1936.

68. Yardibi, H., Turkay, C., 2008. The effects of vitamin E on the antioxidant system, egg production and egg quality in heat stressed laying hens. Turk J. Vet. Anim. Sci. 32(5): 319-325.

69. Zulovich, J. M., DeShazer, J. A., 1990. Estimating egg production declines at high environmental temperatures and humidities. ASAE Paper No. 904021. St. Joseph, Michigan, USA.

\section{Figures}

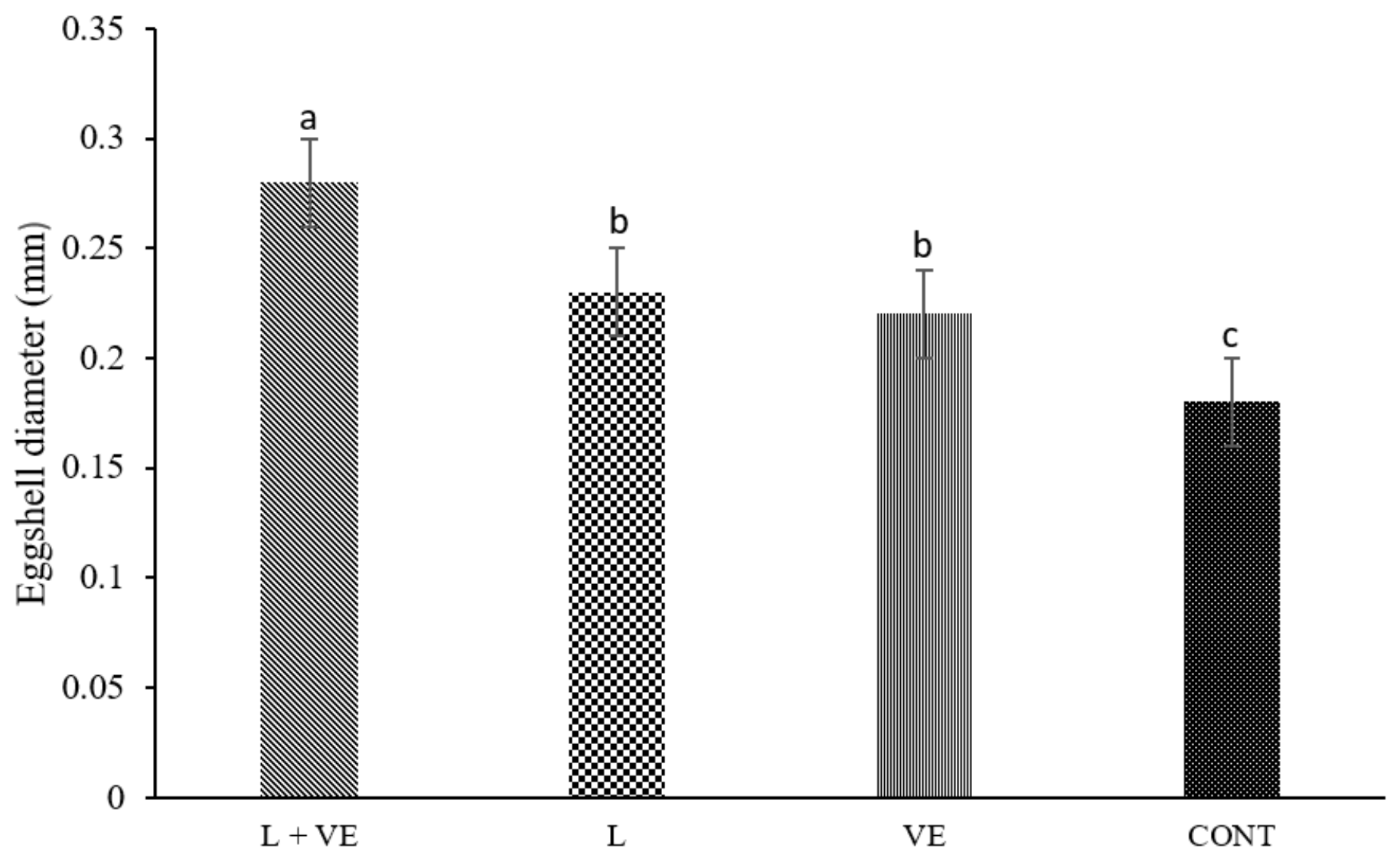


Figure 1

Overall mean eggshell diameter in ISA Brown laying hens during the hot-dry season $a, b, c=$ Values with different superscript letters between layer groups are significantly $(P<0.05)$ different. $L+V E=$ lycopene + vitamin E-administered hens; $\mathrm{L}=$ lycopene-administered hens; VE = vitamin E-administered hens; CONT = control hens.

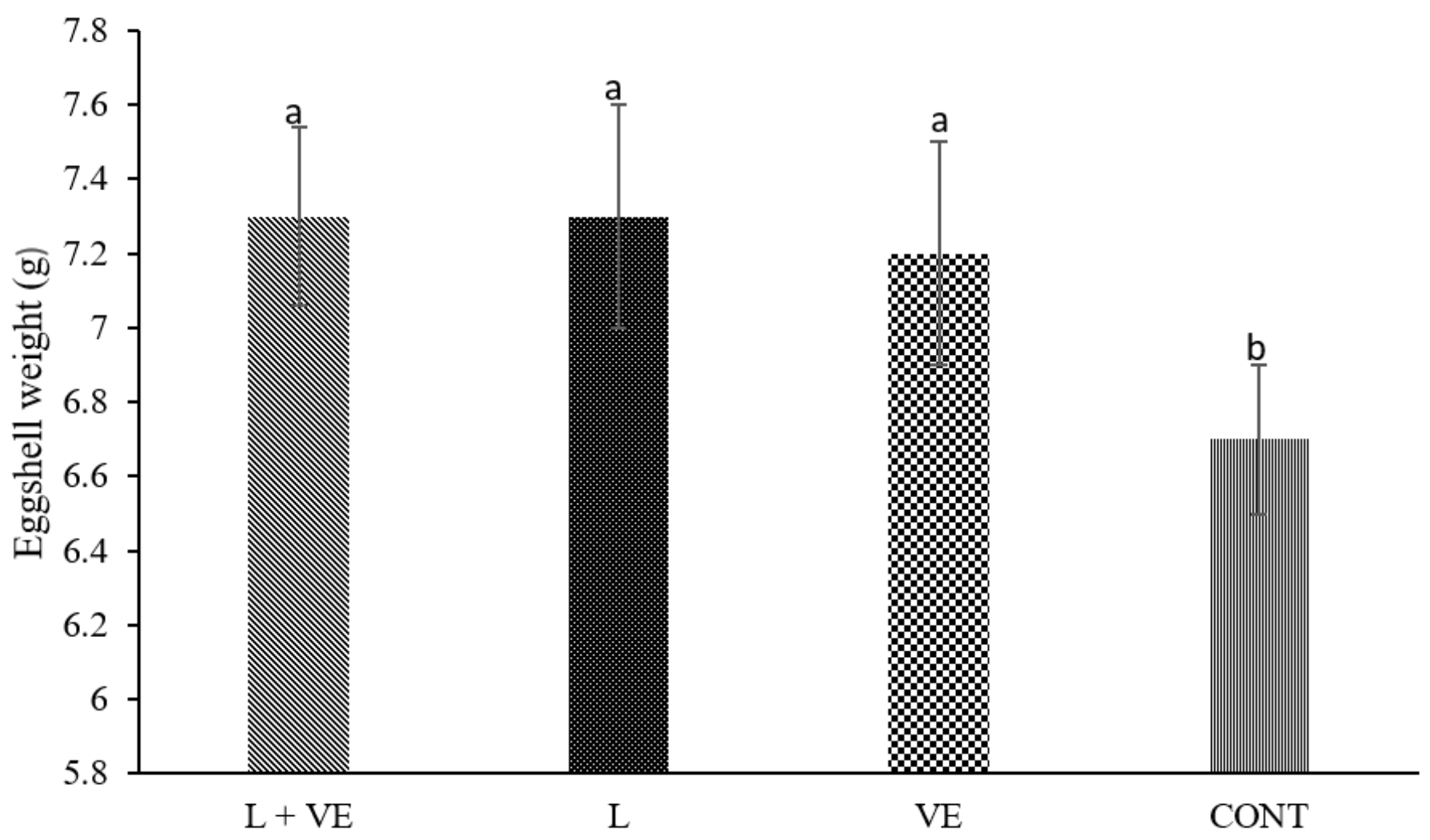

Figure 2

Overall mean eggshell weight in ISA Brown laying hens during the hot-dry season $a, b, c=$ Values with different superscript letters between layer groups are significantly $(P<0.05)$ different. $L+V E=$ lycopene + vitamin E-administered hens; $\mathrm{L}=$ lycopene-administered hens; VE = vitamin E-administered hens; $C O N T=$ control hens. 